\title{
Capitalist Diversity on Europe's Periphery
}

\section{Dorothee Bohle and Béla Greskovits}

\section{Edited by Peter J. Katzenstein}

Ithaca, NY: Cornell University Press, 2012, pp. 287

ISBN 978-0-8014-7815-4

doi:10.15179/ces.16.2.6

The emergence of different types of capitalist regimes across Eastern Europe during post-socialist transition has shifted scholarly interest away from analyzing what countries need to do in order to "become capitalist democracies" and directed it towards a more complex research agenda on the various structural, political and social configurations that make this regime diversity possible.

An example of this shift emerged during the second half of the 2000s, when attempts were made to extend the Varieties of Capitalism (VoC) typology beyond the Western liberal market economies (LMEs), epitomized by the US and the UK, and the coordinated market economies (CMEs), as represented by Germany and Japan. These attempts included the identification of South European economies as mixed market economies (Molina and Rhodes, 2007) and Latin American economies as hierarchical market economies (Schneider, 2009). Eastern European countries have been attributed a greater regime diversity. While the Baltic states have been identified as the LME type, Slovenia has been classified as a CME (Feldmann, 2006). The Visegrád countries, on the other hand, have been identified as belonging to a completely different type, the so-called dependent 
market economies (DMEs), due to their external dependency on capital and innovation as drivers of economic growth (Nölke and Vliegenthart, 2009).

The VoC framework was developed as a response to the ideas of an ever-increasing institutional convergence of consolidated capitalist economies amid growing globalization. It argued that the institutional stability of LMEs and CMEs is related to the complementarities that have developed between production, education and welfare state institutions that cannot be easily changed, and that this stability counteracts the forces of globalization (Hall and Soskice, 2001). In contrast, Eastern Europe has seen enormous institutional turmoil following the collapse of communism and its transitions have been strongly shaped by the international forces of capital. The extension of the $\mathrm{VoC}$ theory to Eastern Europe has therefore been criticized on the grounds that it does not lend itself well to cases characterized by institutional instability. Furthermore, labelling countries as hybrid versions of the existing forms of capitalist diversity in the West does not really advance the theoretical body of knowledge in the area (Schelkle, 2012).

In lieu of these attempts to extend the VoC framework eastwards, Capitalist Diversity on Europe's Periphery by Dorothee Bohle and Béla Greskovits offers a more authentic interpretation of emerging capitalisms in the region. In doing so, the two scholars address a long-standing need to analyze Eastern European capitalisms as something more than hybrids of the Western "ideal types" of production systems. They also successfully challenge the usefulness and relevance of contemporary Western analytical frameworks in explaining the emergence of post-socialist political economies. In that respect, this book represents a much needed and valuable contribution to the study of comparative political economy in Eastern Europe. The new paradigm that Bohle and Greskovits propose offers a promising foundation for the accumulation of new theoretical knowledge on Eastern European capitalist and democratic development.

The book differentiates between the neoliberal orders that developed in the Baltics, the embedded neoliberalism of the Visegrád states and the neocorporatist order that developed in Slovenia. It also analyzes the weak states and unstable regimes that have emerged in the Southeastern EU member states: Bulgaria, Croatia and Romania. Apart from proposing a typology of these different capitalist regimes, 
the book examines, in careful detail, the factors that led to these different regional equilibria. The book therefore enriches our understanding of postsocialist transition by providing a layered account of processes that took place, and offers a roadmap on how to assess these multiple dimensions of transition, whether they were successful or not.

Capitalist Diversity on Europe's Periphery proposes a novel theoretical framework, inspired by Karl Polanyi's work, which the authors' argue is suitable for the specific circumstances of Eastern Europe. Polanyi's The Great Transformation, first published in 1944, analyzes the social and political upheavals that took place in England during the rise of the market economy. Polanyi argued that the endemic problem of capitalism is the fundamental conflict between market efficiency, social cohesion and political legitimacy. By analyzing how these conflicts were negotiated and resolved in post-socialist Eastern Europe, Bohle and Greskovits theorize the role of economics and politics in post-socialist transition and argue that the main burden of sustaining capitalism is placed on the political sphere. Furthermore, the book is framed as an intellectual enquiry into the conditions that made the establishment of capitalist democracy in Eastern Europe possible under adverse conditions.

Bohle and Greskovits also read Polanyi's characterization of capitalism as a multilevel phenomenon, where both the international and the national spheres matter. This motivates them to explain the emergence of the different types of capitalist regimes in Eastern Europe through the interplay of different influences: political decisions and past legacies on one hand and transnational actors on the other. This argument stands in stark contrast to the VoC literature, which assumes the prior existence of established and consolidated national institutions that resist global forces of convergence and that reduce the role of political forces in shaping these outcomes. This angle of analysis is particularly valuable because it helps us to understand the extent to which post-socialist countries have been able to influence their own paths of capitalist development or have been affected by external circumstances. Thus, the book also contributes to the well-known "structure versus agency debate" in the social sciences. 
The first chapter introduces the Polanyian theoretical framework, which is the backbone of the book's argument. Polanyi perceived the market society as a dynamic interaction between economic, social and political contradictions, which is reflected in the tension between three core institutional areas: the marketization of the economy, the opposing goal of protection of society, and the political system, broadly conceived. Bohle and Greskovits extend this triad of politics, social protection and the market into a diamond shaped model by adding democracy, corporatism and macroeconomic coordination as additional constraints that pull the system in different directions (as illustrated in Figure 1.1, p. 21).

The second chapter maps the international and domestic actors involved in the construction of capitalist democracy projects in the region. The chapter explores how these actors have influenced and shaped institutional change with a particular focus on the role of domestic agency in these processes. The authors first identify the initial choices the countries made in terms of their transitional development paths, and then focus on the role of uncertainty and economic crises in determining how these initial choices were translated into practice (this component represents the Polanyian tension between the market and social forces). They finally examine the role of transnational actors, such as the EU and transnational corporations (TNCs), in influencing these processes and limiting the choices available to domestic decision makers (which reflects the multi-level politics dimension of the Polanyian framework). The specific paths of capitalist development that were followed by each region are examined in the subsequent chapters, which display an impressive amount of painstakingly assembled empirical evidence to support the book's theoretical framework.

Chapter 3 presents the case of neoliberal capitalism in the Baltics, where Offe's "triple transition" to the nation-state, market economy and democracy took place (Offe, 1991). The rapid transformation and liberalization of these economies occurred with little political pressure to compensate the losers, the authors argue. As a result, the Baltic states never established a significant welfarist social contract, and their focus was on increasing the contribution of welfare to economic development and growth rather than redistribution and passive monetary compensation. However, following the growing poverty of workers 
and the initial painful transformations, strong economies emerged. The absence of political pressure is attributed to the fact that these countries' reforms were politically tied to the process of nation-state building and removal of Russian influence. As the authors argue, the perceived threat of Russia united the people politically and made it feasible to impose a high economic and social cost on the population.

Chapter 3 goes on to discuss the culture of macroeconomic stability that became entrenched in the Baltic region. The introduction of national currencies and independent monetary policies made the Baltic states internationally creditworthy, and also led to their initial rejection of the euro (as they trusted their own institutions more than the EU). They also introduced flat tax regimes, which revealed a neoliberal preference for seemingly simple institutions that would in theory serve to restrict the power of politics. In examining the politics of these macroeconomic and fiscal reforms, the authors explore the Polanyian tension between international and domestic actors.

Chapter 3 also addresses the issue of substantial discrimination of the Russian minority in the Baltics during transition, which shaped the privatization outcomes. The authors argue that privatizing national assets to foreigners was seen as less of a threat to national sovereignty than selling them to the locals, as Russian minorities would inevitably derive a portion of these assets. The authors also differentiate between the three countries, identifying Estonia as the lead reformer, followed by Latvia, while Lithuania is identified as a reform laggard. A detailed investigation of the Estonian economic miracle is presented. Finally, the chapter reflects on the role of the EU accession in reinforcing these countries' development trajectories.

Chapter 4 looks at the case of embedded neoliberalism in the Visegrád states, as reflected in their contradictory and costly objectives of FDI-led reindustrialization and large welfare state expenditures. These four countries have transformed their economies "into one of Europe's largest transborder clusters of complexmanufacturing export industries" (p. 138). In order to achieve this, they attracted FDI with substantial financial incentives while offering social compensation to 
the losers of economic restructuring. As the authors go on to show, this strategy has come at the cost of significant macroeconomic strains.

The authors also explore how the political elites in the Visegrád countries dealt with economic and democratic transformation amid efforts to build their nation states and simultaneously deal with the process of greater integration into the global economy. Many levels of politics are explored in this chapter. Struggles in the domestic political arena are examined, as well as the competition among the countries to attract foreign capital. The authors also analyze how transnational actors, such as TNCs, but also EU integration projects, such as the EMU, affected these processes. They argue that all of these forces in combination reinforced but also undermined the region's institutions of embedded neoliberalism and created an unstable, transitional equilibrium.

The authors differentiate between Poland and Hungary on one hand and the Czech Republic and Slovakia on the other. Because of their previous exposure to the market and to democracy, business elites in Poland and Hungary were attractive partners for foreign investors. In contrast, Czechoslovakia did not have a macroeconomic burden, so it could more freely choose which development model to follow. Another interesting point that Bohle and Greskovits make on the Visegrád case study is that these countries' institutional convergence is more of an accident than a predictable result of the initial trajectories they followed. This argument stands in contrast to the plethora of literature which emphasizes these countries' similarities. According to Capitalist Diversity on Europe's Periphery, these outcomes were very far from those that domestic reformers had initially intended to achieve, indicating the low impact of past legacies. For example, the authors argue that domestic politicians did not initially pursue development based on foreign direct investment, as it did not fit well with their politics of nation building. Thus, their initial efforts at national development made their eventual adoption of FDI-led strategies of economic restructuring appear as surprising outcomes.

The authors strengthen their case for the low impact of past legacies by showing that although the Visegrád countries initially attempted to reform and strengthen social dialogue, tripartism eventually disintegrated due to a lack of political 
will. Consequently, labor retained little policy influence, a feature that was compensated by a strong welfare state. A contradiction is identified in the promarket stance of these countries and their welfare state expenditures (especially large in the case of pensions), especially for Poland and Hungary. Yet, the pursuit of this welfarist model helped them to manage low levels of social inequality during transition and maintain political stability.

Although significant domestic agency is identified in the case of the Visegrád countries, the second part of Chapter 4 examines the role of interregional rivalry, TNCs and the EU in the emergence of embedded neoliberalism. By the end of the 1990s, models of nationally led development were dropped and the foreignled model was adopted in all four countries. Regional rivalry is discussed in a historical context, and it is acknowledged that these countries never really moved towards a model of regional cooperation prior to EU accession although they were encouraged to do so by the EU. The authors also show how TNCs set the countries against one another in bidding for investments they desperately needed. The chapter concludes with open questions which merit future research, such as how successful this strategy of foreign-led reindustrialization has been, since corporate tax competition has reduced these countries' income base. Moreover, it did little for their future economic prospects, as they remain in the lower value segments of global production chains.

Chapter 5 focuses on Southeastern EU member states. It analyzes the emergence of neocorporatism in Slovenia, and juxtaposes it to the establishment of weak states in Bulgaria, Romania and Croatia. The first part of the chapter discusses the initial strength of trade unions in the region. In the case of Slovenia, strong trade unions in combination with a capable state (defined as more than a government) led to meaningful inclusion of labor into the process of transition and consequently to the emergence of neocorporatist capitalism. In the other three countries, the authors pinpoint weak state capacity, rather than zealous pursuit of neoliberal policies, as the main reason for the weakening of the political power of labor. While the chapter identifies the legacy of patrimonial communism based on patronage and clientelism as the reason behind the weak state in Bulgaria and Romania, state weakness in the case of Croatia is associated with nationalism and the aftermath of the 1991-1995 war. 
Following the analysis of the political strengths and weaknesses of labor in the region, the focus of Chapter 5 moves onto capital, as reflected in privatization, foreign investment and industrial restructuring, and its impact on state capacity. All four countries experienced a continuity in political and economic elites and an insider-led process of privatization and restructuring. The authors note the puzzling empirical observation that insider-driven restructuring did not seem to pose a problem for Slovenia, whereas it did for the other three countries. While Slovenia's FDI and industrial restructuring strategy was arguably successful, in Bulgaria and Romania foreign-led economic restructuring reflected unfair bargaining between weak states and the most mobile type of capital. The final part of Chapter 5 links industrial relations to monetary policy and explains how these countries started to close the gap with the rest of the Eastern EU member states by the mid 2000s. It also examines the role of international financial institutions, such as the IMF and the World Bank, as well as the EU's integration conditionality, in shaping economic outcomes in the Southeast European region and argues that their influence has been stronger here than elsewhere in Eastern Europe.

Chapter 6 investigates the role that the crisis has played in shaking the foundations of the East and Southeast European market economies. The core argument of this chapter is that the political sphere has the primary role in tackling the crisis, as political circumstances, rather than the depth of economic recessions, are likely to determine how they will reposition themselves vis-a-vis the EU and the global economy. The chapter covers each region in a separate section and deals with the exceptional Hungarian economic and democratic crisis in greater detail. It also discusses the erosion of Slovenian neocorporatism. The chapter concludes that although recovery has generally been remarkable and fast, the degree of uncertainty following the crisis is greater than ever for these countries' future paths because the current institutional solutions, i.e., identity politics in the Baltics, welfarism in the Visegrád countries and neocorporatism in Slovenia, have begun to show signs of erosion. The chapter ends with many open questions about the solutions needed to resolve this new set of tensions between markets and democracy in the region. 
The final chapter serves to tie together the stories from the previous chapters and to summarize the book's contribution to scholarship. The chapter "rules out" some of the competing explanations of the divergent patterns of capitalist development in the region, which tend to overemphasize the role of path dependency, or cultural proximity. Instead, the authors advocate a stronger role for political agency. The tensions between Offe's triple transition and its inherent contradictions, as well as the ability of Eastern European countries to overcome them, are also examined. The authors argue that some kind of solidarity is a necessary condition for the establishment of capitalist democracy, whether based upon national identity or social protection or a combination of the two. However, they also warn that such solidarity has an expiry date, and that it is important to understand the role of the international system in maintaining the Polanyian tensions and keeping the destructive forces of anti-capitalism at bay. The book ends by underscoring the role of individual countries, and not just regime types, in maintaining future capitalist stability in the region, reinforcing the importance of political agency. Future trajectories of Eastern European countries are predicted to move towards greater neoliberalism, which "opens a new round of struggles against capitalism's propensity to weaken its own social and political foundations" (p. 269). The predictive power of their Polanyian framework thus detects the rise of nationalism but also the rise of social "countermovements" as new social forces of resistance to growing marketization and uncertainty.

Capitalist Diversity on Europe's Periphery is likely to become an influential research exercise in political economy, which neatly ties a number of elements into one, theoretically coherent, framework. It is important to keep in mind, however, that grasping the sometimes convoluted Polanyian theoretical framework presented in Chapter 1 is crucial for understanding the book's content beyond a compilation of an impressive body of empirical evidence on the Eastern European transitions to capitalism. In that sense, the book is a linear read; one has to start from the beginning in order to grasp the full novelty of the argument. Therefore, more emphasis could have been placed on helping the reader understand how each chapter fits into the Polanyian framework. 
In terms of the book's shortfalls, the balance between structural forces and political agency is often unclear, as well as the balance between transnational and domestic influences. The book puts domestic political agency on a pedestal, which sometimes seems like an imposition rather than a natural conclusion stemming from empirical evidence. For example, little attention is paid to the political economy of EU trade policy (e.g., protectionism in the textiles and clothing industry during the 1990s) or to the economic structure of EU-15, which may have shaped the type of capital that was attracted into the region. There is also an implicit assumption that the EU has had a liberalizing and democratizing influence, without deeper examination of Europeanization as a shaping force in the region. Governments are also presented as handmaidens of the social contract, which may not be the case in reality. Vanhuysse (2006), for example, also emphasizes that political stability, which was ensured by the welfarist social contract, was in fact important for FDI attraction.

Furthermore, the Marxist intellectual tradition of tension between "wild" capitalism and the tendency of the society to tame it, which is reflected in the book's Polanyian framework, can be questioned in its own right. John Kenneth Galbraith, in his seminal 1958 book The Affluent Society, argues that the conflict between economic security, which reduces risk for all economic actors, and economic progress, which is perceived as driven by competitive forces and uncertainty, does not exist in reality. He argues that the modern firm's main aim is to reduce economic risk rather than thrive in the uncertainty of the market. The role of the state is thus to reduce risk for all economic players and who gets more of the state's resources depends on their relative power. In the case of the Visegrád states, the governments can be perceived as reducing economic risk for TNCs as the most powerful economic actors, by delivering to them financial subsidies and political stability through welfare payments to the population. This argument implies a much weaker position of the domestic political actors than the Polanyian framework suggests.

The book also leaves a few components of the Eastern European political economies undertheorized. There is barely any mention of educational systems and their role in shaping and sustaining these capitalist democracies. The 
countries' skill regimes are, for example, an extremely important component of the $\mathrm{VoC}$ literature, which perceives them to be complementary to welfare states and production regimes. Because they define the welfare state as a passive provider of cash transfers, Bohle and Greskovits' Polanyian framework appears to be somewhat anachronistic. Furthermore, there is little reflection on the rise of the service economy, which as an important area of employment has redefined labor relations in Eastern Europe, as elsewhere.

Finally, the narrow definition of the welfare state as solely based on transfers which is used in Capitalist Diversity on Europe's Periphery creates an inherent male bias in the book's typology. Many of the social services that are not included in the typology are directed at defamilialization of caring needs and as such are more relevant for women. This critique is part of the common feminist assessment of regime typologies, including the VoC (e.g., Estévez-Abe, 2006) and Esping-Andersen's worlds of welfare (Lewis, 1992; Orloff, 1993). Inclusion of social services into the typology might have challenged the book's notions of embedded and disembedded capitalisms. Furthermore, apart from this male bias in the typology of welfare states, the book does not reflect on the role of women in sustaining the identified regime typologies, although it identifies as the main driver of these countries' transitions the construction of identity and solidarity politics, which has a clear gender component to it. Gal and Kligman (2000), for example, compellingly argue that gender relations and ideas about gender have shaped political and economic change in Central and Eastern Europe during transition. In this respect, the book falls short of its aim to assess the multiple aspects of transition in all their complexity.

In conclusion, Capitalist Diversity on Europe's Periphery represents a valuable reference for scholars of Eastern Europe, but also for those who are interested in the question of stability of capitalist democracy in today's emerging economies more generally. As such it is a must-read for anyone who is interested in contributing to the future of political economy research in the region and wider. As Komarek (2014) argues, in light of the deep economic, political and social crisis that Europe finds itself in today, there is a lot to learn from the experience of "post-communist countries and their peoples, both before and after 1989" 
(p. 192). Capitalist Diversity on Europe's Periphery was awarded the 2013 Stein Rokkan Prize for Comparative Social Science Research and Dorothee Bohle and Béla Greskovits received the Central European University 2014 Award for Outstanding Research, which is strong evidence that this book is likely to pave the way for a new generation of political economy theories for Eastern Europe and stimulate further theoretical interest in the region.

\section{Literature}

Estévez-Abe, Margarita, 2006, "Gendering the Varieties of Capitalism: A Study of Occupational Segregation by Sex in Advanced Industrial Societies", World Politics, 59(1), pp. 142-175. http://dx.doi.org/10.1353/wp.2007.0016

Feldmann, Magnus, 2006, "Emerging Varieties of Capitalism in Transition Countries: Industrial Relations and Wage Bargaining in Estonia and Slovenia", Comparative Political Studies, 39(7), pp. 829-854. http://dx.doi. org/10.1177/0010414006288261

Gal, Susan and Gail Kligman, 2000, The Politics of Gender After Socialism, Princeton, NJ: Princeton University Press.

Galbraith, John Kenneth, 1999, The Affluent Society, London: Penguin Books (original work published in 1958).

Hall, Peter A. and David W. Soskice, 2001, Varieties of Capitalism: The Institutional Foundations of Comparative Advantage, Oxford: Oxford University Press. http://dx.doi.org/10.1093/0199247757.001.0001

Komarek, Jan, 2014, "Waiting for the Existential Revolution in Europe", International Journal of Constitutional Law, 12(1), pp. 190-212. http://dx.doi. org/10.1093/icon/mou004

Lewis, Jane, 1992, "Gender and the Development of Welfare Regimes", Journal of European Social Policy, 2(3), pp. 159-173. http://dx.doi. org/10.1177/095892879200200301 
Molina, Oscar and Martin Rhodes, 2007, "The Political Economy of Adjustment in Mixed Market Economies: A Study of Spain and Italy" in Bob Hancké, Martin Rhodes and Mark Thatcher, eds., Beyond Varieties of Capitalism: Conflict, Contradictions, and Complementarities in the European Economy, pp. 223-252, Oxford: Oxford University Press. http://dx.doi.org/10.1093/acprof:o so/9780199206483.003.0008

Nölke, Andreas and Arjan Vliegenthart, 2009, "Enlarging the Varieties of Capitalism: The Emergence of Dependent Market Economies in East Central Europe", World Politics, 61(4), pp. 670-702. http://dx.doi.org/10.1017/ S0043887109990098

Offe, Claus, 1991, "Capitalism by Democratic Design? Democratic Theory Facing the Triple Transition in East Central Europe”, Social Research, 58(4), pp. 865-881.

Orloff, Ann Shola, 1993, "Gender and the Social Rights of Citizenship: The Comparative Analysis of Gender Relations and Welfare States", American Sociological Review, 58(3), pp. 303-328, cited in Schelkle (2012). http://dx.doi. org/10.2307/2095903

Schelkle, Waltraud, 2012, "Collapsing Worlds and Varieties of Welfare Capitalism: In Search of a New Political Economy of Welfare”, LEQS Discussion Paper, No. 54, November, London: LSE.

Schneider, Ben Ross, 2009, "Hierarchical Market Economies and Varieties of Capitalism in Latin America", Journal of Latin American Studies, 41(3), pp. 553575. http://dx.doi.org/10.1017/S0022216X09990186

Vanhuysse, Pieter, 2006, Divide and Pacify: Strategic Social Policies and Political Protests in Post-Communist Democracies, Budapest and New York, NY: CEU Press.

Sonja Avlijaš

European Institute, LSE 